\title{
Selection of Potential Probiotic Strains Isolated from Human Intestinal Tract and Traditional Ferment Milk
}

\author{
Chao-hui XUE ${ }^{1, a *}$, Chun YUE ${ }^{2, b}$, Xue-guo LIU $^{3, c}$ and Le YUAN ${ }^{4, d}$ \\ ${ }^{1}$ College of Biological and Chemical Engineering,Nanyang Institute of Technology. \\ Nanyang, China \\ ${ }^{2}$ College of Biological and Chemical Engineering,Nanyang Institute of Technology. \\ Nanyang, China \\ ${ }^{3}$ College of Biological and Chemical Engineering,Nanyang Institute of Technology. \\ Nanyang, China \\ ${ }^{4}$ College of Biological and Chemical Engineering,Nanyang Institute of Technology. \\ Nanyang, China \\ a873790844@qq.com, b903681445@qq.com, 512460415@qq.com, \\ 531166246@qq.com
}

Keywords: Lactobacillus rhamnosus, Salmonella, Diarrhoea, Low pH, Bile salts.

\begin{abstract}
Diarrhea is the main reason of human deaths in developing countries, which also cause world-wide infant mortality. Diarrhoea occurs world-wide and causes $4 \%$ of all deaths and $5 \%$ of health loss to disability. It is most commonly caused by gastrointestinal infections which kill around 1.5 million people globally each year, mostly children in developing countries. In this study, five selected Lactobacillus isolated from human intestinal and ferment milk were preliminarily identified by $16 \mathrm{~S}$ rDNA gene sequencing and assessed the ability to inhibit the infection of enteropathogens. The Lactobacillus strains were screened on the basis of probiotic characteristics (i.e., resistance to low $\mathrm{pH}$ and bile salts, adhesion to the human gastrointestinal tract, inhibition of pathogenic strains). Using an in vitro system simulating gastric transit, our findings indicated that the probiotic strains had the ability to tolerate gastroenteric environment and the adhesive capacity to HT-29 cells. It was demonstrated that the probiotic strains inhibited subsequent adhesion of pathogens to the HT-29 cell. Among the selected strains, the selected Lactobacillus rhamnosus F0533 showed a high probiotic potential and could be used in health-promoting food products. After analyzing the sequence of the 16SrDNA regions of these three strains, the potential probiotic F0533 were Lactobacillus rhamnosus.
\end{abstract}

\section{Introduction}

Probiotics are live microorganisms refers to a class when a sufficient amount of human use will survive in the gut, and have beneficial effects on the human body . 1907 Mece Kafelnik ov that " longevity drinking yoghurt can not old doctrine ," the 1830s Dr. Tian Ren found can reach the intestine alive Yakult bacteria , and its efficacy in-depth study, shows the lactic acid bacteria and not just for dairy fermentation bacteria , but the beneficial intestinal flora balance , helpful for human health, bacteria , beneficial to human health such bacteria are called probiotics $[1,2]$. Since the early 1990 s, all kinds of " probiotic" health products swept the entire world. At the same time, " probiotics" research has become a hot research topic internationally. What are probiotics ? Probiotics comes from the Greek letter "probios" for the meaning of life, probiotics dates back to the early history of mankind, the Greeks and Romans 
have started eating cheese and fermented dairy products, especially to children and patient rehabilitation period of use[3-5] .

Diarrhea is the leading cause of child deaths in developing countries leads to diarrhea in addition to the direct cause health problems, but also cause human nutritional disorders, slowed growth, mental development and other issues [6]. With the development of diagnostic techniques in recent years, people began to study the causes of diarrhea, thus causing diarrhea mechanism for better understanding[7] . Therefore, inhibition of diarrhea caused by bacteria will be able to effectively suppress the occurrence of diarrhea, diarrhea caused by bacteria , including the process of adhesion, growth and invasion of other processes, screening can inhibit the major screening indicators diarrhea probiotic bacteria is inhibiting the growth of pathogenic bacteria and adhesion[8, 9].

The mechanism(s) underlying the antibacterial activity of probiotic strains appears to be multifactorial and includes lowering of the $\mathrm{pH}$ and the production of lactic acid and of antibacterial compounds, including bacteriocin and non-bacteriocin, non-lactic acid molecules [10-12]. Lactic acid bacteria (LAB) can produce antimicrobial substances with capacity to inhibit the growth of pathogenic [13]. Some studies reported that the antagonistic effect of the spent culture supernatants (SCS) of lactic acid bacteria either is due to the production of organic acids or bacteriocins. However, currently investigation showed that some undissociated acid acts an important role by collapsing the electrochemical proton gradient, or by altering the cell membrane permeability which results in disruption of substrate transport systems [14].

The aim of this study was to apply established in vitro tests to evaluate the probiotic potential of Lactobacillusstrains isolated from human intestinal tract and traditional ferment milk, and to select candidate probiotic strains that fulfill the established criteria and could therefore be potentially used as novel probiotic strains in the food industry.

\section{Material and Methods}

\section{Bacterial Strains and Growth Conditions}

Salmonella typhimurium(ATCC14028)strains were grown in Trypticase Soy Broth at $37^{\circ} \mathrm{C}$ for $24 \mathrm{~h}$. Lactobacillus rhamnosus F0533 isolated from human intestinal tract in our laboratory were used in the study. The probiotic strains were routinely cultured under anaerobic conditions on De Man-Rogosa-Sharpe (MRS) medium supplemented with $0.05 \%$ (w/v) cysteine hydrochloride, which was sterilized at $121^{\circ} \mathrm{C}$ for $20 \mathrm{~min}$.

HT-29 Cell Culture. The HT-29 cell was obtained from Harbin Medical University in China and maintained in RPMI 1640 medium with 90\% RPMI 1640(Sigma, St. Louis, MO, USA), penicillin (50U ml- 1 ), streptomycin $(50 \mu \mathrm{g} \mathrm{ml}-1)$ and $10 \%$ foetal bovine serum (Sigma, St. Louis, MO, USA) at $37^{\circ} \mathrm{C}$ in an atmosphere of $5 \% \mathrm{CO} 2$ air. The HT-29 cell were incubated for $12 \mathrm{~h}$ at $37^{\circ} \mathrm{C}$ in $5 \% \mathrm{CO} 2$ atmospheric air and finally the cell were seeded at a concentration of $5 \times 105$ cells/well.

\section{Screening the Probiotics Inhibiting the Growth of Pathogens.}

For detection of antimicrobial activity, an agar spot test was used. Test cultures were spotted ( 2 to $3 \mathrm{ml}$ ) on the surface of MRS agar containing only $0.2 \%$ glucose and $1.2 \%$ agar and incubated anaerobically for $24 \mathrm{~h}$ at $30^{\circ} \mathrm{C}$ to develop the spots. The inhibitory effect of MRS was tested as a negative control on each plate. A $100-\mathrm{ml}$ volume of an overnight culture of the indicator bacteria was mixed with $7 \mathrm{ml}$ of soft agar (0.7\%), using MRS agar for the lactic acid 
bacteria and brain heart infusion agar for the non-lactic acid bacteria, and poured over the plate. The plates were incubated either anaerobically (lactic acidbacteria) or aerobically (non-lactic acid bacteria) at $37^{\circ} \mathrm{C}$. After $48 \mathrm{~h}$ of incubation, inhibition zones were read.

Screening the Probiotics Inhibiting the Adhesion of Pathogens. Inhibition of enteropathogen Salmonella by Lactobacillus rhamnosus F0533 from colonizing HT-29 cell line was studied by the following assays. After monolayers were washed twice with sterile PBS buffer, the mixture of $1 \mathrm{ml}$ probiotics and pathogens suspension and 1ml RPMI 1640 medium were injected into each wells and cultured for $2 \mathrm{~h}$ at $37^{\circ} \mathrm{C}$. The pathogens suspension was not incubated as the control. After incubation, monolayers were washed twice with sterile PBS and afterwards the cells were lysed with $0.5 \%$ Triton X-100 in PBS. The number of bacteria was determined by counting of CFU per milliliter.

Screening the Probiotics able to adapt to Intestinal Environmental. The tests were performed in round-bottom microwell plates (Nunclon). A 200-ml volume each of MRS (pH $1.5,2.0,2.5)$, MRS containing $0.3 \%$ oxgall, or normal MRS, each inoculated with the test bacteria at a level of 106 cells $/ \mathrm{ml}$, was tested in each of four wells. As a control, broth without inoculationwas used. Changes in optical density at $620 \mathrm{~nm}$ (OD620) were measured (Multiscan MCC 340; Labsystem) following $24 \mathrm{~h}$ of incubation at $37^{\circ} \mathrm{C}$. Survival under the different conditions was tested after $4 \mathrm{~h}$ of incubation at $37^{\circ} \mathrm{C}$ and plating of $100 \mathrm{ml}$ onto MRS agar.

In Vitro Adhesion Assay.For the adhesion assay, monolayers of the HT-29 cell were prepared on glass coverslips placed in 6-well tissue culture plates. The HT-29 cell were incubated for $12 \mathrm{~h}$ at $37^{\circ} \mathrm{C}$ in $5 \% \mathrm{CO}_{2}-95 \%$ atmospheric air and finally the cell were seeded at a concentration of $5 \times 10^{5}$ cells/well. After monolayers were washed twice with sterile PBS buffer, the mixture of $1 \mathrm{ml}$ probiotics supernatant $\left(1 \times 10^{8} \mathrm{cfu} \mathrm{mol}^{-1}\right)$ and $1 \mathrm{ml}$ RPMI 1640 medium were injected into each well and cultured for $2 \mathrm{~h}$ at $37{ }^{\circ} \mathrm{C}$. After washing three times with PBS, monolayers were fixed in 10\% formaldehyde for $2 \mathrm{~h}$, dried in air, Gram-stained and examined microscopically. Adherence index was expressed by calculating mean values of adhesive bacteria per 100 cells of cell line in 10 random microscopic fields.

Identification of Screened Probiotic Strains Using 16S rDNA. The conservative and polymorphous $16 \mathrm{~S}$ rDNA were used to identify selected probiotic strains. All probiotics were sub-cultured in a MRSC broth at $37^{\circ} \mathrm{C}$ for $24 \mathrm{~h}$. DNA stool Mini Kit (Solarbio, Beijing, China) was then used to prepare the genomic DNA of the screened probiotics. PCR was performed in a programmable thermal cycle. The universal $16 \mathrm{~S}$ rDNA gene forward and reverse primers were AGAGTTTGATCCTGGCTCAGG and ACGGCAACCTT GTTACG AGTT, respectively. The reaction mixture $(10 \mu \mathrm{l})$ for PCR of the $16 \mathrm{~S}$ regions consisted of a reaction buffer $\left(0.8 \mu\right.$ lofeach DNTP; $1 \mu 1 \mathrm{PCR}$ reaction buffer; $3.2 \mu 1$ sterile $\mathrm{H}_{2} \mathrm{O} ; 5 \mathrm{U} / \mathrm{ml} \mathrm{Tag} ; 0.8 \mu 1$ of $\mathrm{MgCl}_{2}$ and $1 \mu$ lof each primer). Each reaction was carried out for 5 min at $94{ }^{\circ} \mathrm{C} ; 35$ cycles of $1 \mathrm{~min}$ at $94{ }^{\circ} \mathrm{C}, 30 \mathrm{~s}$ at $55^{\circ} \mathrm{C}$, an initial extension for $2 \mathrm{~min}$ at $72^{\circ} \mathrm{C}$, and a final extension for 10 min at $72^{\circ} \mathrm{C}$. Reaction mixtures were subsequently cooled to $4^{\circ} \mathrm{C}$. The PCR products were then sent to the Sangon Biotech Co. Ltd (Shanghai, China) for sequencing of $16 \mathrm{~S}$ regions. Homology searches of the databases were done with the BLAST program (http://www.ncbi.nlm.nih. gov/BLAST). 


\section{Results and Discussion}

Screening the Probiotics Inhibiting the Growth of Pathogens. It was demonstrated that the probiotic strains inhibited subsequent adhesion of pathogens to the HT-29 cell. Among the selected strains, Lactobacillus rhamnosus F0533 showed a high probiotic potential and could be used in health-promoting food productst.

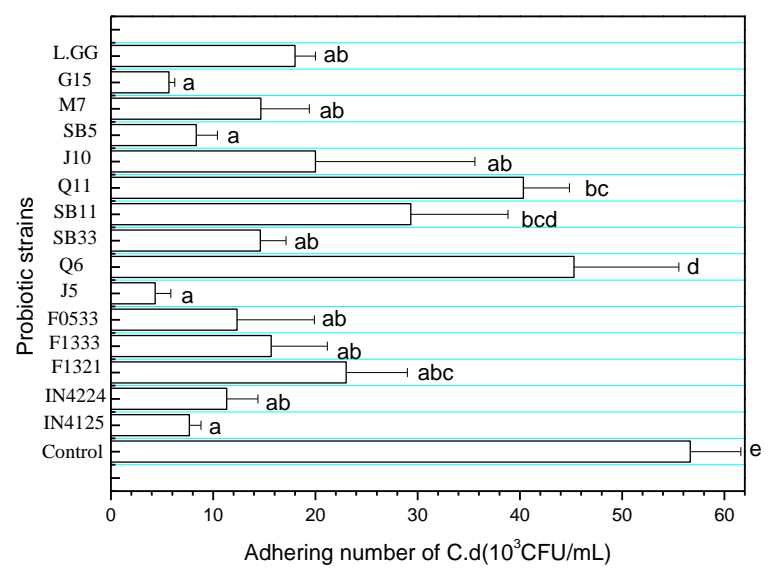

Fig 1 Lactobacillus strains potentiates barrier function in HT-29 monolayers.HT-29 cells were exposed to Lactobacillus rhamnosus F0533.

Screening the Probiotics able to adapt to intestinal Environmental. The number of surviving cells was determined following incubation with low $\mathrm{pH}$ MRSC broths for $2 \mathrm{~h}$ by plating them on MRSC agar medium. When MRSC broth was adjusted to $\mathrm{pH} 2$ to simulate low-pH conditions of human gastrointestinal tract, the enumeration of viable organisms was shown in Table 1. Viable bacteria numbers declined about $2 \log$ unit compared with those before incubation $(0 \mathrm{~h})$. The effect of bile salt on cell growth was examined by adding oxgall (Sigma, St. Louis, MO, USA) to a final concentration of $0,0.30,0.50 \%$ (w/v). The OD of probiotics was measured at $600 \mathrm{~nm}$. According to Table 2, different concentrations of bile salts could inhibit growth of lactobacillus, depending on the concentration of bile salts. It has been reported that lactobacillus had distinctly different effects at $0.3 \%$ bile salts.

Table 1 Effecte of gastric juice on viability of $\operatorname{strains}(\bar{x} \pm \mathrm{SD}, \mathrm{n}=3)$

\begin{tabular}{cccc}
\hline Strains & \multicolumn{3}{c}{ viability of strains $(\mathrm{CFU} / \mathrm{mL}) \mathrm{lg}$} \\
\cline { 2 - 4 } & $\mathrm{pH} 1.5$ & $\mathrm{pH} 2.0$ & $\mathrm{pH} 2.5$ \\
\hline IN4224 & $5.33 \pm 0.34 \mathrm{a}$ & $7.27 \pm 0.20 \mathrm{bc}$ & $7.86 \pm 0.07 \mathrm{a}$ \\
J5 & $6.08 \pm 0.21 \mathrm{ab}$ & $7.77 \pm 0.04 \mathrm{~d}$ & $8.39 \pm 0.09 \mathrm{~b}$ \\
LGG & $5.40 \pm 0.46 \mathrm{a}$ & $7.29 \pm 0.12 \mathrm{bc}$ & $8.07 \pm 0.08 \mathrm{a}$ \\
SB33 & $5.51 \pm 0.45 \mathrm{a}$ & $6.86 \pm 0.23 \mathrm{a}$ & $8.43 \pm 0.07 \mathrm{~b}$ \\
G15 & $5.45 \pm 0.54 \mathrm{a}$ & $6.81 \pm 0.08 \mathrm{a}$ & $8.46 \pm 0.03 \mathrm{~b}$ \\
IN4125 & $6.21 \pm 0.48 \mathrm{ab}$ & $6.91 \pm 0.09 \mathrm{ab}$ & $8.46 \pm 0.10 \mathrm{~b}$ \\
M7 & $6.72 \pm 0.39 \mathrm{~b}$ & $7.60 \pm 0.07 \mathrm{~cd}$ & $8.39 \pm 0.08 \mathrm{~b}$ \\
F0533 & $6.28 \pm 0.27 \mathrm{ab}$ & $7.00 \pm 0.13 \mathrm{ab}$ & $8.40 \pm 0.19 \mathrm{~b}$ \\
\hline
\end{tabular}

Note: Values followed by different letters in the same column are significantly different $(P<0.05)$ 
Table 2 Effecte of different concentrations of bile salt on growth of $\operatorname{strains}(\bar{x} \pm \mathrm{SD}, \mathrm{n}=3)$

\begin{tabular}{cccc}
\hline Strains & \multicolumn{3}{c}{ viability of strains (CFU/mL) lg } \\
\cline { 2 - 4 } & Control & $0.3 \%$ & $0.5 \%$ \\
\hline IN4224 & $8.62 \pm 0.03 \mathrm{a}$ & $6.10 \pm 0.20 \mathrm{a}$ & $5.64 \pm 0.11 \mathrm{a}$ \\
J5 & $8.92 \pm 0.05 \mathrm{~b}$ & $7.24 \pm 0.14 \mathrm{~b}$ & $6.45 \pm 0.09 \mathrm{~b}$ \\
LGG & $8.90 \pm 0.04 \mathrm{~b}$ & $7.33 \pm 0.12 \mathrm{~b}$ & $6.05 \pm 0.08 \mathrm{ab}$ \\
SB33 & $8.52 \pm 0.05 \mathrm{a}$ & $6.78 \pm 0.20 \mathrm{ab}$ & $5.33 \pm 0.12 \mathrm{a}$ \\
G15 & $9.07 \pm 0.05 \mathrm{c}$ & $7.48 \pm 0.12 \mathrm{c}$ & $6.46 \pm 0.03 \mathrm{~b}$ \\
IN4125 & $8.82 \pm 0.04 \mathrm{ab}$ & $7.43 \pm 0.11 \mathrm{~b}$ & $6.46 \pm 0.10 \mathrm{~b}$ \\
M17 & $8.67 \pm 0.03 \mathrm{a}$ & $7.53 \pm 0.17 \mathrm{c}$ & $5.79 \pm 0.08 \mathrm{a}$ \\
F0533 & $8.88 \pm 0.02 \mathrm{ab}$ & $7.33 \pm 0.13 \mathrm{~b}$ & $6.40 \pm 0.19 \mathrm{~b}$
\end{tabular}

Note: Values followed by different letters in the same column are significantly different $(P<0.05)$

In Vitro Adhesion Assay.Bacterial adhesion to intestinal cells was one of the most crucial selection criteria for probiotic strains. Adherence capacities of the probiotics were performed using HT-29 cells, a cell line used as an in vitro model for intestinal epithelium. In our study, the viable adherent bacteria were measured by enumeration. The adherence index of probiotic stains was about 110 adhesive bacteria per 100 cells. Gilliland et al. [13] stated that Lactobacillus strains with high acid and bile resistance showed better growth and colonization character in the small intestine than non-resistant strains.

Identification of Screened Probiotic Strains. Polymerase chain reaction (PCR) assays and group-specific primers designed from the nucleotide sequences of the $16 \mathrm{~S}$ rDNA were used to identify the screened probiotic strains. According to the sequencing results, the three strains F0533 appeared to be Lactobacillus rhamnosus based to 99\% homology from a BLAST search in NCBI.

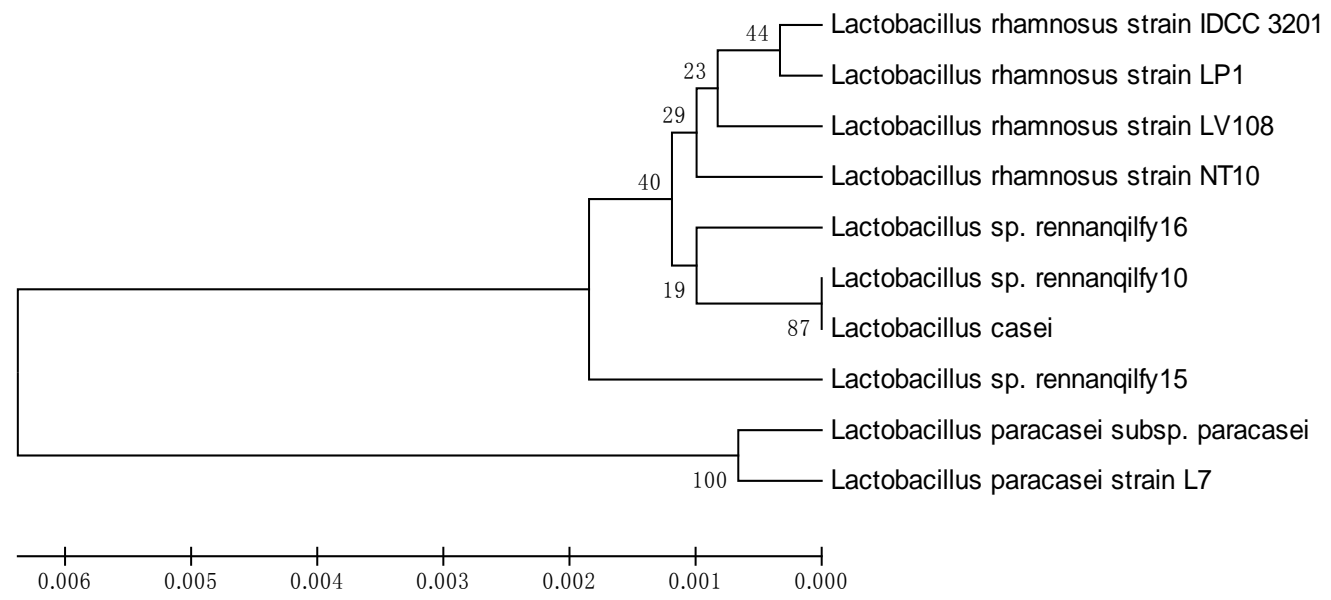

Fig 2 Phylogenetic tree of Lactobacillus rhamnosus F0533.

\section{Summary}

Lactobacilli have long been associated with beneficial effects in the human intestine, however, the mechanisms underlying the benefits have not been sufficiently elucidated. Here, we investigated the effects of Lactobacillus rhamnosus F0533 on HT-29 monolayers serving as a model for the intestinal epithelial barrier. The strains varied in ability to tolerate acid and bile, 
adherence properties and cholesterol assimilation which indicate that selection of probiotics has to be carefully undertaken.

\section{References}

[1] Theresa J. Ochoa, MD, Eduardo Salazar-Lindo, MD, and Thomas G. Cleary, MD. Management of Children With Infection-Associated Persistent Diarrhea. Semin Pediatr Infect Dis, 2004(15):229-236.

[2] Liong MT, Shah NP, Acid and bile tolerance and cholesterol removal ability of lactobacilli strains. J Dairy Sci, 2005(88):55-66.

[3] Sheil B, Shanahan F, O’Mahony L. Probiotic Effects on Inflammatory Bowel Disease. The Journal of Nutrition, 2007(137):819s 824s.

[4]IsolauriE, Sütas Y, Kankaanpää P,et al. Probiotics: effects on immunity. American Journal of Clinical Nutrition, 2001(73):444s 450s.

[5]Gareth C Parkes, Jeremy D Sanderson, Kevin Whelan. The mechanisms and effi cacy of probiotics in the prevention of Clostridium diffi cile-associated diarrhoea.Lancet Infect Dis, 2009(9): 237 44.

[6] Vicki Lei, Henrik Friis , Kim Fleischer Michaelsen.aSpontaneously fermented millet product as a natural probiotic treatment for diarrhoea in young children: An intervention study in Northern Ghana. International Journal of Food Microbiology, 2006(110): 246-253.

[7]Henryk Szymánski, Agnieszka Chmielarczyk, Magdalena Strus, Jerzy Pejcz, Mirosław Jawie'n, Piotr Kochan, Piotr B. Heczko. Colonisation of the gastrointestinal tract by probiotic L. rhamnosus strains in acute diarrhoea in children. Digestive and Liver Disease, 2006 (2):274-276.

[8] Wen, H.L., Chien, K.L., Sen, J.S., Chin, F.H., Wan, T.Y., Wen, Z.H. and Hau, Y.T., 2009. Antagonistic Activity of Spent Culture Supernatants of Lactic Acid Bacteria against Helicobacter Pylori Growth and Infection in Human Gastric Epithelial AGS Cells. J.Food Sci 74-6.

[9] Deraz, S.F, Karlsson, E.N., Khalil, A.A., Mattiasson, B., 2007. Mode of action of acidocin D20079, a bacteriocin produced by the potential probiotic strain, Lactobacillus acidophilus DSM. J IndMicrobiol Biotechnol 34, 373-9.

[10] Ashokkumar, S., Sree, K.R., Pavithrab, V., Hemalathab, V. and Priya, I., 2011. Production and antibacterial activity of bacteriocin by Lactobacillus paracasei isolated from donkey milk. INT J CURR SCI 1, 109-115.

[11] Servin AL., 2004. Antagonistic activities of lactobacilli and bifidobacteria against microbial pathogens. FEMS Microbiol Rev 28, 405-40.

[12] Ridwan, B.U., Koning, C.J.M., Besselink, M.G.H., Timmerman, H.M., Brouwer, E.C., Verhoef, J., 2008. Antimicrobial activity of a multispecies probiotic against pathogens isolated from infected pancreatic necrosis. Lett Appl Microbiol 46, 61-7. 
[13] Zalan, Z., Hudacek, J., Stetina, J., Chumchalova, J., Halasz, A., 2010. Production of organic acids by Lactobacillus strains in three different media. Eur Food Res Techno 230, 395-404.

[14] Olusegun, A.O, Abiodun A.O. and Christine E.R.D., 2008. Identification of Pediococcus spp. From Beef and Evaluation of Their Lactic Acid Production in Varying Concentrations of Different Carbon Sources. Advances in Natural and Applied Sciences 2, 197-207. 